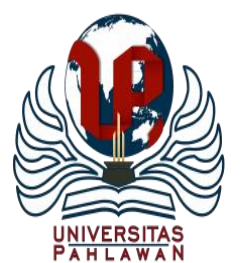

Jurnal Abdidas Volume 2 Nomor 3 Tahun 2021 Halaman 498-504

JURNAL ABDIDAS

http://abdidas.org/index.php/abdidas

\title{
Meningkatkan Minat Kewirausahaan pada Kelompok PKK Kelurahan Bintara Jaya
}

\author{
Tyna Yunita $^{1}$, Rini Wijayaningsih ${ }^{2}$, Dhian Tyas Untari $^{3}$, Adi Wibowo Noor Fikri ${ }^{4}$ \\ Manajemen, Fakultas Ekonomi dan Bisnis, Universitas Bhayangkara Jakarta Raya, Indonesia ${ }^{1,2,3,4}$ \\ E-mail : tyna.yunita@gmail.com ${ }^{1}$,wijayariniwijaya@yahoo.com ${ }^{2}$, tyas_un@yahoo.co.id ${ }^{3}$, \\ noor.fikri@gmail.com ${ }^{4}$
}

\begin{abstract}
Abstrak
Ibu-ibu rumah tangga dengan sejumlah aktivitas keseharian, berperan penting dalam pertumbuhan dan pendidikan anak anak. Seorang ibu membutuhkan energi yang besar untuk beraktivitas dan memotivasi seluruh anggota keluarga. Ibu rumah tangga juga diharapkan dapat mendukung ekonomi keluarga. Banyaknya tuntutan sebagai ibu rumah tangga dalam menyelaraskan kegiatan harian, maka seorang ibu harus kreatif. Kegiatan ini bermaksud memberikan pelatihan pembuatan bunga dari sabun, sehingga dari hasil kreativitas ini ibu-ibu rumah tangga dapat membantu perekonomian keluarga dan juga memotivasi ibu-ibu rumah tangga dalam meningkatkan kualitas diri. Kegiatan ini dilakukan pada kelompok PKK RW.014, Kelurahan Bintara Jaya, Kecamatan Bekasi Barat, Kota Bekasi dengan memberikan praktik pelatihan dari pengolahan bahan baku hingga pemasaran pada ibu-ibu rumah tangga yang menjadi peserta di dalam kegiatan ini. Kegiatan PKK menjadi ajang silaturahim dan berdampak positif dengan perluasan wawasan dari kacamata akademisi. Hasil kegiatan ini dapat meningkatkan minat kewirausahaan, kreativitas dan apabila ditekuni akan menambah pendapatan keluarga. Selain itu, dengan pelatihan ini diharapkan ibu-ibu untuk dapat kreatif menggunakan sumber daya yang ada.
\end{abstract}

Kata kunci: minat kewirausahaan, ekonomi keluarga, motivasi, kreativitas

\section{Abstract}

Housewives, with some daily activities, play an essential role in the growth and education of their children. A mother needs much energy to move and motivate all family members. Homemakers are also expected to be able to support the family economy. There are many demands as a housewife in harmonizing daily activities, so a mother must be creative. This activity is intended to provide training on making flowers from soap so that from the results of this creativity, housewives can help the family economy and motivate homemakers to improve their quality. This activity was carried out in the PKK RW.014 Kelurahan Bintara Jaya, West Bekasi District, Bekasi City, provides practical training from raw material processing to marketing to homemakers who are participants in this activity. PKK activities become a gathering place and have a positive impact by expanding the perspective of academics. The results of this activity can increase entrepreneurial interest, creativity and, if practiced, will increase family income. In addition, with this training, it is hoped that mothers can be creative in using existing resources.

Keywords: interest in entrepreneurship, family economics, motivation, creativity

Copyright (c) 2021 Tyna Yunita, Rini Wijayaningsih, Dhian Tyas Untari, Adi Wibowo Noor Fikri

$\triangle$ Corresponding author

Address : Universitas Bhayangkara Jakarta Raya

Email : tyna.yunita@gmail.com

ISSN 2721- 9224 (Media Cetak)

DOI : https://doi.org/10.31004/abdidas.v2i3.308

ISSN 2721- 9216 (Media Online) 


\section{PENDAHULUAN}

Problema kesejahteraan keluarga menjadi salah satu permasalahan yang perlu mendapat perhatian khusus, dalam hal ini ibu-ibu baik secara pribadi, kelompok atau masyarakat berperan penting dalam kesejahteraan dan pendidikan keluarga. Hingga dapat diketahui bahwa ukuran kesehatan tidak hanya aspek fisik, mental, sosial saja, tapi juga termasuk aspek produktivitas secara ekonomi maupun secara sosial. Ibu merupakan pendidik utama bagi anak anaknya. Sebagai bagian dari dunia pendidikan, seorang ibu dalam mengerjakan aktivitas harian haruslah sehat fisik dan rohani. Sebagaimana diketahui bahwa pendidikan dimulai dari rumah, peran ibu dalam rangka menciptakan sumber daya manusia yang berkualitas, sangatlah dibutuhkan. Para ibu inilah yang berperan penting bagi perkembangan generasi mendatang untuk dibekali dengan pendidikan dan pelatihan yang diharapkan dapat meningkatkan taraf hidup masyarakat.

Kegiatan yang dilakukan ibu ibu kelompok PKK melalui pelatihan kewirausahaan ini menjadi salah satu upaya yang berdampak dalam membantu perekonomian keluarga, seiring meningkatkan pengetahuan dan keterampilan peserta pelatihan (Latipah, 2020).

Para ibu yang tergabung dalam kelompok PKK dapat berperan dalam peningkatan kesejahteraan keluarga. Kelompok-kelompok PKK di lingkungan dusun atau lingkungan, RW, RT, yang atas persetujuan Presiden dan dibentuk dengan 10 program PKK tahun 1988, bertujuan meningkatkan pembinaan warga. Pelatihan pengelolaan keuangan sangat diperlukan dalam mengelola keuangan rumah tangga agar dapat menyesuaikan dengan pemasukan dan mengelola prilaku konsumtif (Mulyanti \& Nurdin, 2018).

Kegiatan pengabdian kepada masyarakat yang didukung Universitas Bhayangkara Jakarta Raya ini merupakan salah satu bagian dari Tri Dharma Perguruan Tinggi. Dengan kegiatan pengabdian kepada masyarakat diharapkan dapat meningkatkan kualitas sumber daya manusia melalui peran ibu-ibu kelompok PKK. Kelompok PKK RW.014 Kelurahan Bintara Jaya ini merupakan salah satu kelompok PKK yang aktif melakukan pertemuan dan kegiatan kreatif. Anggota kelompok PKK ini merupakan ibu ibu rumah tangga yang berdomisili di RW.014 Kelurahan Bintara Jaya, Kecamatan Bekasi Barat, Kota Bekasi.

Kegiatan ini juga sebagai ajang sosialisasi dan kesempatan untuk bertukar informasi. Ibu merupakan manager rumah tangga dengan sejumlah aktivitas keseharian, berperan penting dalam pertumbuhan dan pendidikan anak anak. Seorang ibu membutuhkan energi yang besar untuk beraktivitas dan memotivasi seluruh anggota keluarga. Ibu rumah tangga juga diharapkan dapat mendukung ekonomi keluarga. Banyaknya tuntutan sebagai ibu rumah tangga dalam menyelaraskan kegiatan harian, maka seorang ibu harus kreatif. Metode pertemuan yang berlangsung tiap bulan dengan kegiatan seperti arisan, dirasa perlu untuk menambah kegiatan yang bermanfaat. Sehingga permasalahan pengelolaan keuangan dapat diberikan pelatihan yang dapat diterapkan untuk dapat secara efektif menggunakan keuangan 
500 Meningkatkan Minat Kewirausahaan pada Kelompok PKK Kelurahan Bintara Jaya- Tyna Yunita, Rini Wijayaningsih, Dhian Tyas Untari, Adi Wibowo Noor Fikri

DOI: https://doi.org/10.31004/abdidas.v2i3.308

berdasarkan kebutuhan dan bukan berdasarkan keinginan.

Peran penting keluarga mendapat perhatian khusus dari pemerintah, sebagaimana tercantum pasal 10 ayat 4 pada Undang-Undang Sistem Pendidikan Nasional nomor 2 menyebutkan bahwa: "Pendidikan keluarga merupakan bagian dari jalur pendidikan luar sekolah yang diselenggarakan dalam keluarga dan yang memberikan keyakinan agama, nilai budaya, nilai moral dan keterampilan" (Undang-Undang Republik Indonesia, 1989). Selanjutnya pemerintah menekankan pembangunan nasional bertujuan untuk memberdayakan peran aktif wanita (Undang-Undang Republik Indonesia, 2000). Salah satu cara untuk memberdayakan wanita adalah dengan kegiatan positif, akan lebih menguntungkan apabila kegiatan tersebut memberikan nilai ekonomi. Kewirausahaan merupakan kemampuan mengembangkan ide dan kreativitas yang inovatif yang dijadikan dasar, tehnik, dan memaksimalkan sumber daya untuk mengembangkan peluang menuju sukses (Latipah, 2020).

Langkah awal mengembangkan kewirausahaan dengan meningkatkan minat kewirausahaan. Minat kewirausahaan merupakan representasi kecenderungan minat untuk memulai atau menciptakan usaha sebagai karir kewirausahaan (Krueger, 2017). Wirausahawan merupakan individu yang memulai dan melaksanakan usaha dengan keberanian untuk menanggung risiko dan memiliki semangat juang menjalankan bisnis hingga berhasil (Prasetyo, 2011). Bidang kewirausahaan ini terkait teori dari bidang lain seperti psikologi dan sosiologi, sehingga para akademisi memetakan pondasi untuk penelitian mengenai proses kognitif individu yang ulet dalam mengeksplorasi minat kewirausahaan ini (Krueger Jr, Reilly, \& Carsrud, 2000).

Kegiatan ini bermaksud memberikan pelatihan pembuatan bunga dari sabun, sehingga dari hasil kreativitas ini ibu-ibu rumah tangga dapat membantu perekonomian keluarga dan juga memotivasi ibu-ibu rumah tangga dalam meningkatkan kualitas diri.

Selain itu tujuan kegiatan dapat diuraikan sebagai berikut:

a) Meningkatkan minat untuk berwirausaha.

b) Memberikan pengetahuan secara teoritis mengenai kewirausahaan.

c) Melatih dan mengembangkan ide kreatif untuk mengolah bahan mudah didapat.

d) Meningkatkan semangat kepada ibu ibu untuk mengunakan waktu secara efektif.

e) Memberi pemahaman pentingnya seorang ibu sebagai role model dalam keluarga.

f) Membentuk jiwa mandiri.

g) Memberdayakan ibu sebagai sumber pendapatan sekunder keluarga.

\section{METODE}

Kegiatan Abdimas dilakukan pada tanggal 7-8 November 2020. Pada tanggal 7 November 2020 merupakan wawancara terkait minat wirausaha para ibu PKK. Pada tanggal 8 November 2020 penyajian materi yang dilakukan di aula RW (gambar 1). Dari 50 undangan yang disebarkan, kegiatan ini dihadiri oleh 32 ibu-ibu 
501 Meningkatkan Minat Kewirausahaan pada Kelompok PKK Kelurahan Bintara Jaya- Tyna Yunita, Rini Wijayaningsih, Dhian Tyas Untari, Adi Wibowo Noor Fikri

DOI: https://doi.org/10.31004/abdidas.v2i3.308

setempat. Ini berarti tingkat kehadiran sebesar 64\%. Mengingat kegiatan pengadian ini diadakan pada masa pandemi COVID-19. Sehingga pada kegiatan ini juga dibagikan masker dan tetap mengikuti protokol kesehatan

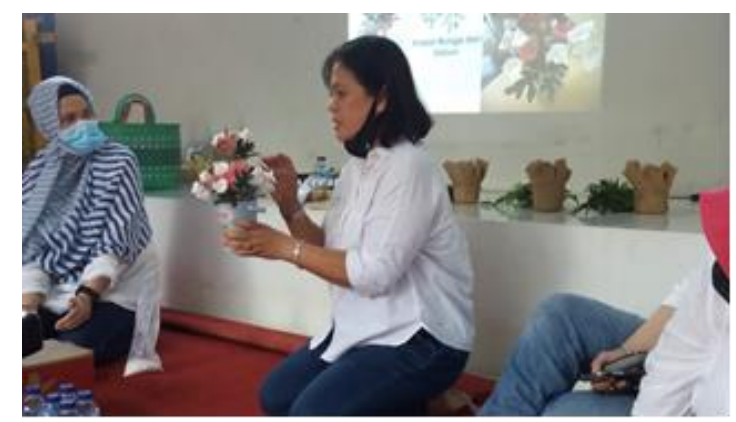

Gambar 1.Penyajian Materi Kreasi Bunga

Kegiatan Abdimas ini dilakukan setelah melalui serangkaian tahapan. Tahap pertama, kegiatan pengabdian kepada masyarakat ini diawali dengan pengamatan dan pengumpulan data. Kegiatan yang dilakukan ibu-ibu merupakan ajang berkumpul. Mengingat pentingnya arti seorang ibu, maka kegiatan PKM ini menjadi sarana bersosialisasi. Sehingga dirasa perlu untuk memberi motivasi, dan transfer pengetahuan agar dapat memberdayakan ibu ibu rumah tangga ini. Selain itu, persiapan kegiatan ini juga termasuk izin kepada ketua RW dan pihak keamanan di lokasi Abdimas.

Selanjutnya adalah penentuan tema. Pelatihan mengolah sabun menjadi bunga memberi kesempatan bagi ibu-ibu kelompok PKK ini untuk dapat menambah keterampilan dan pengetahuan serta dapat meningkatkan minat berwiraswasta. Pelatihan pemanfaatan kreasi bunga ini sebagai langkah awal untuk menanamkan pola pikir kewirausahaan dan dapat dikembangkan untuk menambah penghasilan keluarga.

Langkah berikutnya adalah mengumpulkan studi pustaka untuk memperluas khasanah dan memberi pemahaman berbagai teori dan implementasi tentang pelatihan manajemen dan praktik kreasi bunga dari sabun. Pemanfaatan kreasi bunga ini merupakan ide bisnis dan apabila ditekuni maka akan menghasilkan pendapatan. Sehingga penting untuk menilai kelayakan bisnis

Berdasarkan rujukan studi pustaka dan selanjutnya materi pelatihan dibuat ke dalam modul pelatihan dan praktik kreasi bunga dari sabun. Materi yang dipersiapkan juga berbasis teori kewirausahaan, pemasaran dan keuangan.

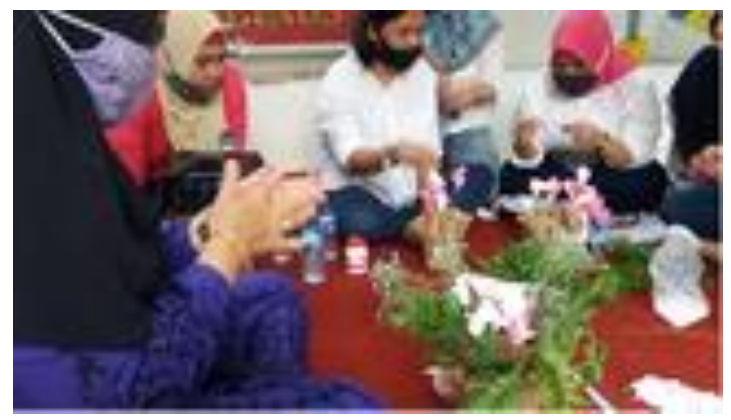

Gambar 2. Praktik Kreasi Bunga

Materi berupa modul yang dipresentasikan, seperti terlihat pada gambar 2 merupakan pembagian bahan baku dan praktik langsung oleh peserta membuat kreasi bunga dari sabun. Dalam sesi dengan tanya jawab, terlihat para peserta sangat antusias mengikuti kegiatan ini, terlihat pada gambar 3. Hal ini merujuk bahwa metode partisipatif digunakan untuk meningkatkan semangat peserta pelatihan dan efektifitas pemahaman materi (Saroinsong, 2019). 


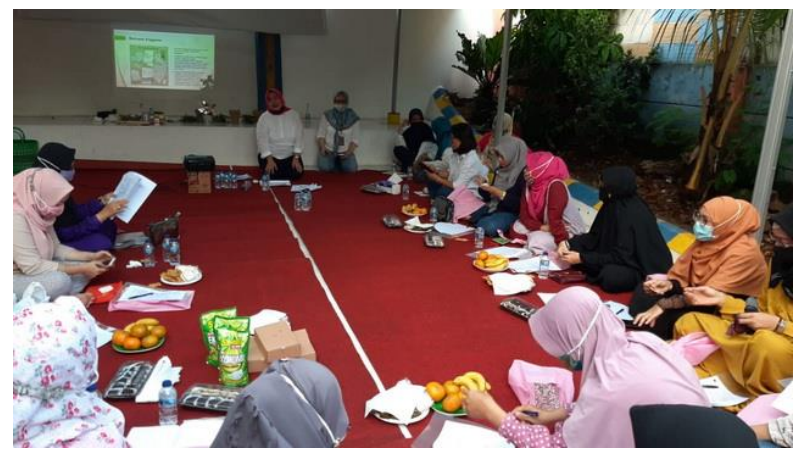

Gambar 3. Pembahasan Materi Pelatihan

Pada bagian akhir kegiatan PKM ini diabadikan dalam bentuk catatan-catatan, foto-foto (gambar 4) dan video yang berhubungan dengan materi pengabdian masyarakat.

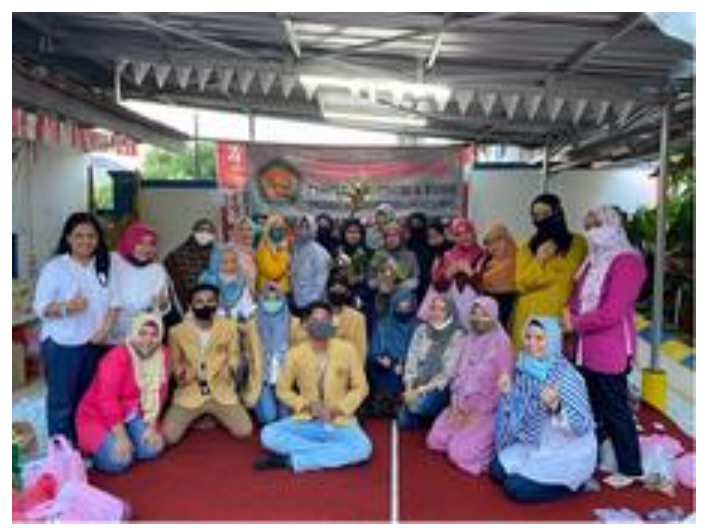

Gambar 4. Foto Bersama Peserta Pelatihan

\section{HASIL DAN PEMBAHASAN}

Kegiatan Abdimas dilakukan dengan presentasi dan praktik untuk menumbuhkan minat dan jiwa kewirausahaan pada ibu-ibu PKK Kelurahan Bintara Jaya. Tim memberikan presentasi dengan beberapa slide dan diakhiri dengan penyampaian materi bagaimana memanfaatkan sabun menjadi produk yang bernilai ekonomis yaitu dengan membuat bunga dan karangan bunga dari sabun. Selain wangi, produk ini juga memiliki nilai ekonomi yang cukup tinggi. Pada materi presentasi juga dibahas mengenai strategi pemasaran dan pengelolaan keuangan untuk membuka wawasan para peserta pelatihan ini.

Tabel 1. Data Deskriptif

\begin{tabular}{|l|c|c|}
\hline Data & Jumlah & Presentase \\
\hline $\begin{array}{l}\text { Kepemilikan usaha: } \\
\text { Sudah memiliki usaha } \\
\text { Pernah mencoba } \\
\text { wirausaha }\end{array}$ & 6 & $18,75 \%$ \\
$\begin{array}{l}\text { Belum pernah mencoba } \\
\text { wirausaha }\end{array}$ & 17 & $53,13 \%$ \\
& 9 & $28,13 \%$ \\
\hline $\begin{array}{l}\text { Kelompok Usia: } \\
20-29 \text { tahun }\end{array}$ & 5 & $15,63 \%$ \\
$30-39$ tahun & 12 & $37,5 \%$ \\
$40-49$ tahun & 13 & $40,63 \%$ \\
50 tahun & 2 & $6,24 \%$ \\
& & \\
\hline Jenis usaha yang & & $43,75 \%$ \\
sudah digeluti: & 14 & $31,25 \%$ \\
Kuliner & 10 & $6,25 \%$ \\
$\begin{array}{l}\text { Pakaian } \\
\text { Kerajinan }\end{array}$ & 2 & $18,75 \%$ \\
Lainnya & 6 & $28,13 \%$ \\
Belum pernah & 9 & $40.62 \%$ \\
\hline Kendala: & 13 & $31,26 \%$ \\
Keuangan & 10 & $28,12 \%$ \\
Keahlian & & \\
Jaringan bisnis & 9 & \\
\hline
\end{tabular}

Dari tabel 1 menunjukan bahwa para peserta pelatihan sudah menunjukan minat kewirausahaan sebesar 53,13\% yang sudah mencoba wirausaha. Meskipun usaha yang dimiliki belum menjadi karir atau pekerjaan utama. Dapat dikatakan kegiatan ini sebagai langkah awal home industry (Sunarsi, Kustini, Lutfi, Fauzi, \& Noryani, 2019). Karena ibu-ibu PKK sebagai penggerak di lingkungan desa atau kelurahan (Widodo et al., 2020).

Dari table 1, kendala keuangan dirasa sebagai penghambat bagi peserta pelatihan ini sebesar 40,62\%. Selain itu, keahlian yang harus 
dikembangkan dan dilatih agar minat kewirausahaan ini dapat menjadi peluang bisnis. Untuk mengasah keahlian ini, adalah perlu untuk proaktif dan pemahaman resiko (Wicaksono \& Nuvriasari, 2012). Salah satu langkah awal untuk mengembangkan kewirausahaan adalah jaringan bisnis. Perlu ada keberanian untuk memulai dari lingkup sosial terkecil.

Sejauh ini terlihat usaha kuliner yang paling diminati sebesar 43,75\%. Usaha kuliner merupakan kegiatan yang akrab dalam keseharian ibu rumah tangga. Dari data menunjukan bahwa $28,13 \%$ belum mencoba berwirausaha, hal ini karena memiliki pekerjaan tetap.

Usia peserta pelatihan ini cukup variatif, dan perlu kajian lebih jauh untuk mengulas minat kewirausahaan di kalangan ibu ibu PKK ini.

Evaluasi kegiatan. Kegiatan Abdimas ini sangat bermanfaat, sebagaimana tertuang pada tujuan untuk meningkatkan minat kewirausahaan. Indikator kegiatan pelatihan ini terlihat dari jumlah peserta yang hadir dan menunjukan semangat mengikuti pelatihan, dan melakukan praktik kreasi bunga. Sebagai evaluasi dari kegiatan Abdimas ini, adalah perlu dilakukan secara berkesinambungan. Kegiatan selanjutnya diarahkan untuk memberi wawasan terkait materi pemasaran dan teknologi.

Kegiatan Abdimas ini memberi dampak positif, yaitu para peserta pelatihan mendapat pengetahuan kewirausahaan, peningkatan keterampilan dan pengembangan wawasan. Pengetahuan sebagai kunci yang terkait dengan proses penciptaan, penyebaran dan pemanfaatannya (Bresciani, Ferraris, \& Del, 2017).

\section{SIMPULAN}

Berdasarkan kegiatan pelatihan ini, maka dapat disimpulkan berwirausaha bukan hanya bagi mereka yang menjadi tulang punggung keluarga, tapi jiwa wirausaha juga harus dimiliki oleh ibu rumah tangga sebagai pengelola dan pendukung keuangan keluarga. Hal ini dapat mendorong kemandirian wanita dan memberdayakan potensi para ibu untuk terus kreatif.

Selain itu, pemanfaatan sabun selama ini hanya sebagai produk kebersihan dan kesehatan (Amalia et al., 2018). Sehingga pemanfaatannya masih sangat terbatas. Dengan diadakan pelatihan pemanfaatan sabun sebagai bunga sabun yang memiliki nilai ekonomis yang cukup tinggi diharapkan dapat menjadi bekal bagi ibu-ibu untuk dapat berwirausaha dan memperkuat keuangan keluarga. Juga, kegiatan ini mendorong ibu-ibu untuk memanfaatkan bahan yang yang ada dan mudah didapat. Sehingga kegiatan ini sekaligus memberi inspirasi untuk memanfaatkan media atau bahan lain yang dapat bernilai ekonomis.

Dengan demikian saran yang dapat diberikan adalah perlu diadakan acara serupa secara terus menerus. Karena merubah paradigma bahwa "ibu rumah tangga cukup dirumah saja dan mencari nafkah adalah kewajiban suami” membutuhkan cukup waktu untuk merubahnya.

\section{UCAPAN TERIMA KASIH}

Penulis mengucapkan terima kasih kepada Lembaga Penelitian, Pengabdian Masyarakat dan Publikasi (LPPMP), Universitas Bhayangkara Jakarta Raya yang telah memberi dukungan financial terhadap kegiatan pengabdian kepada 
504 Meningkatkan Minat Kewirausahaan pada Kelompok PKK Kelurahan Bintara Jaya- Tyna Yunita, Rini Wijayaningsih, Dhian Tyas Untari, Adi Wibowo Noor Fikri

DOI: https://doi.org/10.31004/abdidas.v2i3.308

masyarakat ini, Dekan Fakultas Ekonomi dan Bisnis yang telah memberikan pertujuan dan arahan dalam kegiatan ini, Ketua RW.14 Kelurahan Bintara Jaya, Bekasi Barat, Ketua PKK Kelurahan Bintara Jaya, Bekasi Barat Serta pihakpihak yang telah mendukung terlaksananya kegiatan pelatihan ini.

\section{DAFTAR PUSTAKA}

Amalia, R., Paramita, V., Kusumayanti, H., Wahyuningsih, W., Sembiring, M., \& Rani, D. E. (2018). Produksi Sabun Cuci Piring Sebagai Upaya Peningkatkan Efektivitas Dan Peluang Wirausaha. Metana, 14(1), 15. https://doi.org/10.14710/metana.v14i1.18657

Bresciani, S., Ferraris, A., \& Del, M. (2017). Technological Forecasting \& Social Change The management of organizational ambidexterity through alliances in a new context of analysis : Internet of Things ( IoT ) smart city projects. Technological Forecasting \& Social Change. https://doi.org/10.1016/j.techfore.2017.03.00 2

Krueger Jr, N. F., Reilly, M. D., \& Carsrud, A. L. (2000). Competing models of entrepreneurial intentions. Journal of Business Venturing, 15(5-6), 411-432.

Krueger, N. F. (2017). Entrepreneurial intentions are dead: Long live entrepreneurial intentions. In Revisiting the entrepreneurial mind (pp. 13-34). Springer.

Latipah, I. (2020). Pemberdayaan perempuan melalui pemanfaatan media Youtube dalam meningkatkan keterampilan wirausaha. Comm-Edu (Community Education Journal), $3(2), 83-90$.

Mulyanti, D., \& Nurdin, S. (2018). Pelatihan Perencanaan Keuangan Keluarga Bagi IbuIbu PKK Kecamatan Cimenyan Kabupaten Bandung. Jurnal Abdimas BSI: Jurnal Pengabdian Kepada Masyarakat, 1(2).

Prasetyo, I. (2011). Telaah Teoretis Model Experiential Learning dalam Pelatihan
Kewirausahaan Program Pendidikan Non Formal. Majalah Ilmiah Pembelajaran, 7(2).

Saroinsong, S. J. R. (2019). Program Kemitraan Masyarakat (PKM) kewirausahaan mahasiswa FIS Unima pembuatan dan pemasaran mie sayur tanpa pengawet. Edupreneur: Jurnal Pengabdian Kepada Masyarakat Bidang Kewirausahaan, 1(4).

Sunarsi, D., Kustini, E., Lutfi, A. M., Fauzi, R. D., \& Noryani, N. (2019). Penyuluhan Wirausaha Home Industry Untuk Meningkatkan Ekonomi Keluarga Dengan Daur Ulang Barang Bekas. BAKTIMAS: Jurnal Pengabdian Pada Masyarakat, 1(4), 188-193. https://doi.org/10.32672/btm.v1i4.1720

Undang-Undang Republik Indonesia. Nomor 2 Tahun 1989 Tentang Sistem Pendidikan Nasional. , (1989).

Undang-Undang Republik Indonesia. Nomor 25 Tahun 2000 Program Pembangunan Nasional (PROPENAS) Tahun 2000-2004. , (2000).

Wicaksono, G., \& Nuvriasari, A. (2012). Meningkatkan Kinerja UMKM Industri Kreatif Melalui Pengembangan Kewirausahaan dan Orientasi Pasar: Kajian pada Peran Serta Wirausaha Wanita di Kecamatan Moyudan, Kabupaten Sleman, Propinsi DIY. Jurnal Sosio Humaniora, 3(4), 27-39.

Widodo, A., Furyanah, A., Widodo, S., Maharani, H., Yulianti, D. M., \& Sina, I. (2020). Pemberdayaan ibu rumah tangga untuk menjadi seorang wirausaha, di wilayah RW 09, kampung Bulak, kelurahan Benda Baru, kecamatan Pamulang, Tangerang selatan Banten. ABDI LAKSANA: Jurnal Pengabdian Masyarakat, 1(1), 126-130. 